\title{
Islamic Character Education as an Effort to Anticipate Intolerance and Disintegration
}

\author{
Fa'iz Nashiroh \\ Institut Agama Islam Negeri (IAIN) Kudus \\ Email: faiznashiroh77@gmail.com \\ Ashif Az Zafi \\ Institut Agama Islam Negeri (IAIN) Kudus \\ Email: ashifazzafi@iainkudus.ac.id \\ Received: January 12, 2021 | Accepted: June 9, 2021
}

\begin{abstract}
This article aims to determine how to anticipate attitudes of intolerance and disintegration that occur in Indonesia. This article uses a descriptive research method. The data was collected by conducting a literature study with information from respondents. In the process, the writer uses a qualitative approach. The author found an effort to anticipate attitudes of intolerance and disintegration by planting Islamic character education with the habituation method in all spheres of life. The results obtained from this study are that intolerance and disintegration can be anticipated by planting Islamic character education with the method of habituation in all spheres of life, both family, school, and society.
\end{abstract}

\begin{abstract}
Abstrak
Artikel ini bertujuan untuk mengetahui bagaimana upaya antisipasi terhadap sikap intoleransi dan disintegrasi yang terjadi di Indonesia. Artikel ini menggunakan metode penelitian deskriptif. Pengumpulan data dilakukan dengan melakukan studi kepustakaan disertai informasi dari responden. Dalam prosesnya, penulis menggunakan pendekatan kualitatif. Penulis menemukan adanya upaya antisipasi terhadap sikap intoleransi dan disintegrasi dengan penanaman pendidikan karakter Islami dengan metode pembiasaan pada semua lingkup kehidupan. Hasil yang diperoleh dari kajian ini adalah intoleransi dan disintegrasi dapat diantisipasi dengan penanaman pendidikan karakter Islami dengan metode pembiasaan di semua lingkup kehidupan, baik keluarga, sekolah, maupun masyarakat.
\end{abstract}

\section{Keywords}

Intolerance, disintegration, Islamic character education 


\section{Introduction}

The Unitary State of the Republic of Indonesia is an archipelago with a variety of diversity that has been recognized in the eyes of the world, with each island or region having its characteristics, such as race, ethnicity, language, culture, etc. and customs that are often referred to as multicultural. Apart from being known as a multicultural country, Indonesia is also known as a multi-religious country which is marked by the number of religions in Indonesia, such as Islam, Christianity, Buddhism, Catholicism, Confucianism, and Hinduism (Redaksi, 2020:1). With such diversity, Indonesia can prove to the world community that the Indonesian people can coexist in harmony and peace under the existing diversity with the motto Unity in Diversity, which means different but still one and Pancasila as the foundation, in which there are noble values that unite the entire Indonesian nation (Herlina, 2018: 233). This shows that Indonesia is a country that upholds tolerance. However, this does not mean that Indonesia is not immune from intolerance.

Intolerance is a form of deviation from tolerance, where one person or group of people does not respect or even hate another group. Intolerance in Indonesia itself has often occurred even before Indonesia's independence, such as the story of the two twin kingdoms of Kasunanan Surakarta and Kasultanan Ngayogyakarta (Azca et al., 2019: 26). Whereas in the world of education, it is prohibited for women who are not from the kingdom to receive an education.

Recently, intolerance in Indonesia has increased significantly. This can be seen from the rejection of Shia groups in Indonesia. Meanwhile, in the world of education, recently there has been an uproar with the news of the obligation to wear Muslim attributes to all students at SMK Negeri 2 Padang where there are also non-Muslim students in the school. It is not only religious differences that often serve as a background for intolerance, but many other factors can trigger an attitude of intolerance. In every religion, it is recommended to tolerate and live in peace. It's just that there are a small number of people who feel disadvantaged and even reject tolerance so that they create issues that can ignite intolerance so that there will be a great upheaval to support them in rejecting tolerance.

Intolerance, if not handled properly and occurs continuously, can be one of the factors triggering disintegration in the community. Disintegration itself is a state of non-unity or in other words, means division (Dewi, 2015: 91). And if there is disintegration in Indonesia, there will certainly be wars and destruction of the Unitary State of the Republic of Indonesia. So, for this reason, there is a need for efforts to anticipate 
attitudes of intolerance and disintegration in Indonesian society. One of the efforts that can be done is by planting the character education of the Indonesian nation by the values in Pancasila.

Islam as a religion that is Rahmatal Lil Alamin advocates tolerance, as has been explained in many verses of the Al-Qur'an and Hadith. And it has also been exemplified by the Prophet Muhammad when he was alive, where he was very tolerant of others even though he was of different religion or ethnicity. So of course all Muslims are obliged to uphold tolerance in life, as long as it is not in the realm of aqidah as explained in the QS. Al-Kafirun verse 6 "To you your religion, to me my religion". In Islam, efforts to anticipate intolerance and disintegration have been very much paid attention to, namely by planting Islamic character education or moral education, both in the family, education or school, as well as in the community. Where the character in Islamic character education is in line with the character of the Indonesian nation which is contained in the values of Pancasila.

Intolerance, disintegration, and character education have been discussed in many articles, both National and International articles. It's just that the discussion is more individual, does not cover all three. Among them in the international journal Al-Jami'ah Journal with the article title $A$ Tale of Two Royal Cities: The Narratives of Islamists' Intolerance in Yogyakarta and Solo, it discusses intolerance in two Islamic kingdoms in Yogyakarta before Indonesian independence which was triggered by a power struggle conflict. in one family (Azca et al., 2019: 28). In the same journal entitled Practicing What It Preaches? Understanding The Contradictions Between Pluralist Theology and Religious Intolerance Within Indonesia's Nahdlatul Ulama explains intolerance between Islamic groups and how NU views it in the eyes of Abdurrahman Wahid (Arifianto, 2017: 244).

The international journal Cakrawala Pendidikan journal with the article titles Teaching-Loving-Caring (Asah-Asih-Asuh) and Semi-Military Education on Character Education Management discusses the application of military-based character education that is strong in the discipline (Sukendar et al., 2019: 293). In another article, The Education of the National Character of Pancasila in Secondary School Based on Pesantren Islamic boarding schools discusses the implementation of national character education based on Pancasila (Sataloff et al., 2017: 423).

Another international journal, namely the Journal of Islam and Muslim Societies with the title of the article Modification of Character Education Into Akhlaq Education for The Global Community Life discusses adjustment to the global community, character education must be modified to become moral education. The two educations are compatible, it's just 
that the context used in character education is more general and morals more inclined to Islam (Sutomo, 2014: 293).

The similarities between this article and the articles above are that both discuss intolerance and character education. It's just that what distinguishes this article is the addition of discussion about disintegration and character education raised in this article is not character education in general, but Islamic character education. Therefore, this article will examine Islamic character education as a manifestation of the anticipation of intolerance and disintegration that occurs in Indonesian society.

These complex problems raise the question of, how can intolerance be the cause of disintegration? And what is the Islamic perspective on intolerance and disintegration? And what anticipatory efforts can be made with Islamic education? A discussion starting from a small problem, then continuing with the view from the religious side of the problem, and finally answering the anticipation that can be done, will make it easier for readers to understand and analyze this article from the smallest to the diver of the problem.

\section{Methods}

This article was prepared using a qualitative approach. Data collection methods or techniques are carried out through interviews and literature study by adopting theories from experts. The data analysis used was descriptive. This article has the benefit of providing an understanding to the public that intolerance and disintegration can be anticipated with character education, especially Islamic character education.

\section{The Nature Intolerance}

Intolerance is the opposite of tolerance, which if tolerance is an attitude of respect, respect, and does not hinder the differences that exist. So intolerance is an attitude of not appreciating, respecting, and appearing to oppose and hinder and hate existing differences (Herlina, 2018: 239). Intolerance in Indonesia is not new anymore, because the history of Indonesia's establishment has been marked by a lot of intolerance. Among them was the case of the seizure of the Islamic kingdom of Yogyakarta before the Indonesian independence era, which in turn made the Yogyakarta kingdom to be divided into two kingdoms, namely the Kasultanan Ngayogyakarta and the Kasunanan Surakarta (Azca et al., 2019: 28). 
Cases of intolerance in the last few years are considered to have increased significantly. This can be seen from the blasphemy case by the governor of Jakarta, Basuki Tjahaja Purnama, several years ago. And the case of intolerance that has just happened and is still hotly discussed comes from the world of education regarding the case of the obligation to wear a headscarf which is an attribute of Muslims, especially for women at SMKN 2 Padang. If analyzed from some of the cases above, the factors behind intolerance mostly come from the field of religion. However, there are many factors behind intolerance. These factors are divided into several fields, including:

First, Religion. The sector field of religion is one of the biggest contributors to intolerance. Bigotry and a lack of deep understanding of religion coupled with the many radical religious currents cause many people to easily fall into opposing things such as intolerance, radicalism, and terrorism (Sholikin, 2018: 6-9). Intolerance in the field of religion does not only occur between religions, but can also occur among other religions, such as opposition to the Shia or Ahmadiyah religions committed by fellow Muslims, and many more.

The second, Social Sector. In social life, the diversity that exists is familiar. And as a society in Indonesia, we are asked to live in harmony and peace in diversity. However, in reality, living in a society with a variety of existing diversity is easy. Many differences lead to intolerance, such as disrespecting differences of opinion during deliberations, refusing to greet or shake hands with neighbors of different beliefs, and so on. In addition, low nationalism, diversity, love for the homeland, and nationalism have made intolerance more prevalent in Indonesian society.

Third, Politics. Politics in Indonesia often creates intolerance in Indonesian society, which can be seen in regional head elections, gubernatorial elections, and even presidential elections. From the regional head elections to the presidential elections, there are several candidates, and each candidate must have its supporters. The supporters certainly want those who are supported to win and will cause resentment against other candidates and supporters. But surely only one of these candidates will be elected, and it will make the other candidates and their supporters disappointed and will hate each other. When this happens continuously and there is no awareness from within a person, there will certainly be greater intolerance (Sanusi \& Muhaemin, 2019: 24). In addition, the strengthening of identity politics can also be a cause of intolerance in the political field.

Fourth, Field of Education. Low education causes a person to be less able to understand problems from several points of view so that this person only uses his or her point of view in assessing a problem. And 
usually, people like that like to go along without having a clear basis. In addition, the differences regarding favorite schools and ordinary schools, public schools, and religious special schools can also create feelings of humiliation for people whose schools are below their school standards, which is the beginning of intolerance among students. Not only that, in the elected president, they are usually asked for those who are majority religious, council bullies of students against minority students, the absence of educators of different religions to balance in decision making, the inclusion of potentially intolerant learning if not explained properly, and others. Religious differences, cultural differences, regional differences, low understanding of the meaning of differences given by parents, and the inclusion of intolerant learning accompanied by educators who are fanatical towards their religion or others are also causes of intolerance in the field of education (Tholkhah, 2013: 9-10).

Fifth, Economic Sector. Economics is often defined as money, which is based on economic actions that result in coffers of money. The relation between economy and intolerance is the difference between one's caste and other people, which is usually synonymous with the caste of the rich and the poor. In Indonesia, this is very common, where rich people always look down on the poor, and some even insult or insult and trample on the selfesteem of the poor, and so on.

Sixth, Field of Law. The field of law is also not free from the emergence of intolerance in society. This can be seen from the many articles on religious affairs, articles on religious blasphemy, and articles on regulations on places of worship (Assyaukanie, 2018: 30-39). These articles will not be a problem if they are not viewed only from a point of view, but if viewed only from one point of view it will certainly lead to intolerance in Indonesia. In addition, from the area of law that can lead to intolerance is the court and law enforcers.

Courts and law enforcers often trigger intolerance, which is now felt by the public that the law is currently monopolized by those who have money. The current law is no longer what it used to be which was sharp upward blunt downwards, but changed to blunt upward sharp downward. This injustice can lead to intolerance and cause public distrust of law enforcement agencies.

Seventh, Cultural or Regional Sector and Language. The diversity of cultures and languages and regions in Indonesia has a high enough risk of intolerance. The intolerance that usually occurs is differences in the meaning of regional languages in other regions, differences in customs or culture in each region, territorial seizure, and many more which usually lead to minor wars such as wars between tribes. 
Continuous intolerance in society and the lack of self-awareness of the differences and diversity that exist in Indonesia can lead to deviant behaviors that appear to lead to disintegration in Indonesia.

\section{The Concept of Disintegration}

Indonesia is a country that upholds integration with evidence of Pancasila, Unity in Diversity, and in the word NKRI (Unitary State of the Republic of Indonesia) there is the word unity, which means integration is unity among existing diversity. The diversity that Indonesia has is very diverse, seen from the many islands where each island has customs, culture, regional language, race, ethnicity, and also Indonesia has various religions, namely Islam, Hinduism, Buddhism, Confucianism, and Christianity (Redaksi, 2020: 1). Besides being the background for integration in Indonesia, this great diversity also sometimes triggers disintegration.

Disintegration has the opposite meaning of integration, namely non-unity or division. In Indonesia's history, disintegration has occurred and resulted in the release of East Timor from the Unitary State of the Republic of Indonesia. If analyzed in-depth, disintegration in Indonesia occurs a lot at any time due to conflicts that have diverse backgrounds. Conflict itself means two people or groups who have a perspective that they have different and conflicting goals (Dewi, 2015: 91). Conflicts or problems that can trigger disintegration in Indonesia, including:

First, Intolerance. Intolerance is an attitude of not appreciating, respecting, and appearing to hate existing differences. If the intolerance in Indonesia is analyzed, the results must be overwhelming. There are no fewer factors behind intolerance, either from oneself or from the environment. In addition to interfaith intolerance, it can also occur in one religion but different schools or schools of thought. Intolerance is the basis for other problems that can lead to disintegration.

Second, Radicalism. Radicalism is an act of violence, anarchism, and extremism that is carried out by people with radical currents against a person or group of people based on defense (Fithriyah \& Umam, 2018: 112). These acts of radicalism usually originate from endless intolerance or in other words, radicalism is an extreme form of intolerance with acts of violence. This act of radicalism seems dangerous because it can lead to many lives at stake. Radicalism can be in the form of small or large wars, as well as acts of terrorism. In addition, many religions have a radical understanding that makes radicalism even more rooted in a person.

Third, Terrorism. Terrorism is an act of violence in the form of terror to frighten the wider community. Acts of terrorism are always identified with bombings in public places and often take many victims. 
Terrorism originated from intolerance which later became radicalism, and from that radicalism arose a desire to carry out jihad by carrying out bombings. So, intolerance, radicalism, and terrorism are interrelated and bound (Sholikin, 2018: 6-9).

Fourth, The Strengthening of Identity. Politics, previously nationalist politics, has now turned into identity politics. Identity politics is politics with identical nuances to something, such as ethnicity, race, religion, skin color, or others. This strengthening of identity politics can be seen in the election for the candidate for governor of Jakarta (Supratikno et al., 2020: 331).

Fifth, The low level of Nationalism Education. Indonesia, which is a country with a lot of diversity, should be instilled in nationalism education so that people have a high spirit of nationalism. Nationalism is a soul or a high sense of nationality. However, in reality on the ground, nationalism education is very minimally applied and even eliminated. This can be seen from the emphasis on academic aspects rather than practice, in which a sense of nationalism requires more practice, not just theory. These problems can still be minimized and avoided by cultivating character education with nuances of nationalism.

\section{The Concept of Character Education}

Character is often interpreted as behavior or characteristic within a person, which differentiates one person from another (Triatmanto, 2010: 188). In the perspective of personality psychology, the character is defined as an assessment of the right and wrong and good and bad behavior of a person, both religiously (morally), culture (morally), and logic (ethically) (Fatwikiningsih, 2020: 4). There is no need to doubt the good and noble character of the Indonesian nation because the noble character of the Indonesian nation has been reflected in Indonesian citizens who have ethics and morals based on the values of Pancasila. The realization of this noble national character cannot be separated from the character education instilled in children from an early age by the family, government, and society.

Character education is broadly interpreted as character education that is natural without being limited by space and time. More narrowly, character education is defined as an effort that is programmed, planned, and has clear targets and goals (Sukiyat, 2020: 7). Plato defines character education as a process of fostering, shaping, and creating a leader who brings goodness and justice to society (Koesoema A., 2007: 112). Meanwhile, according to Lickona, character education has a definition as an effort taken seriously in helping someone to know, love, and do well based on ethical values. In line with Lickona, Albertus stated that character 
education is a place for individuals to freely live up to noble values that are good to be used as guidelines and applied in their daily behavior, both to God, themselves, and fellow humans.

The conclusion from some of the definitions of experts regarding the meaning of character education is that character education is an effort made consciously and planned in facilitating and directing students to know and love good and noble values, have intellectual competence, and have a strong will in terms of fighting for kindness and nobility, and wise in making decisions. Thus, the essence of character education is value education which is used to help and facilitate students to become good people (Supriyadi, 2011: 114). In obtaining character education, more often it is attributed or identified as formal education. However, in essence, character education can be obtained from anywhere, both internally and externally such as family, friends, and society, not only an informal education (Ramadhan, 2017: 29-30). Many characters can be obtained by children from various fields and experiences in life. However, in the world of education, the National Education Ministry stipulates 18 (eighteen) characters that must be obtained and taught to children, namely religion, honesty, tolerance, discipline, hard work, creativity, independence, democracy, curiosity, national spirit, love of the land. water, appreciates achievement, is friendly or communicative, loves peace, loves reading, cares about the environment and society, and is responsible. In line with Diknas, the Indonesia Heritage Foundation (IHF) also defines these characters and then simplifies them into 9 pillars of character, namely the love of God Almighty and all of His creation, independence and responsibility, honesty (trust) and wise, respect and courtesy. generous, helpful and cooperative, confident, creative, and hard work, leadership and justice, kind and humble, tolerance, peace, and unity (Sutomo, 2014: 295-296).

\section{Results and Discussion}

Intolerance is not a new discussion for the people of Indonesia. Talking about intolerance, recently the problem of intolerance has become a byword in society again with the emergence of news about the obligation to wear a headscarf for female students at SMK Negeri 2 Padang which is a public school, which in general are not only Muslim but also students. other religions. The problem of intolerance in the education sector happens a lot, it's just not exposed by the media. The problem of intolerance is not only in the field of education, but in other fields, intolerance can occur or become a cause of intolerance.

The intolerance that occurs continuously will lead to a spirit of radicalism or violence. If the spirit of intolerance and radicalism is deeply 
rooted in a person or society, along with a minimal understanding of religion and an individualistic viewpoint, it can lead to terrorism. If these complex and interrelated problems are not immediately handled properly and the absence of self-awareness in a person or society, will trigger disintegration or division. And if this happens, then it is certain that the destruction of the Unitary State of the Republic of Indonesia is certain.

Every religion strongly advocates peace and tolerance. Assays Shalom in Christianity, this means peace (Supratikno et al., 2020: 334). The word Shalom in Christianity, if examined has a similarity with the word Salam in Islam which also means peace. As the largest religion in the world and the majority religion in Indonesia, Islam highly values peace and tolerance. This is evidenced by the many verses of the Al-Qur'an and Hadith that explain peace and tolerance, one of which is the word of Allah in QS. Al-Baqarah verse 208, which reads:

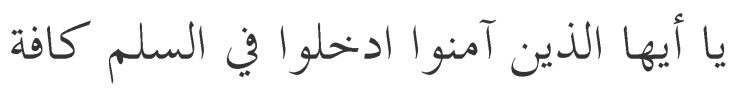

"O you who believe, enter into Islam whole and do not obey the steps Satan. Satan is a real enemy."

In the interpretation of Al-Misbah by Quraish Shihab, this verse describes the command to love peace and avoid enmity and division, both between religions and within one religion, because this is a satanic way. And warfare in Islam is only allowed to uphold peace and justice (Shihab: 2001).

Based on the interpretation of the verse, it can be concluded that Islam highly respects tolerance and peace, and prohibits hostilities and wars both within one religion and between religions. To minimize the occurrence of these complex problems, as well as to create peace in the world, especially in Indonesia, anticipatory efforts are needed in the form of planting Islamic character education for all Muslims, especially Muslims.

Character education itself has the aim of making someone a Kamil (perfect human). Which, is in line with the goals of Islam. So it can be understood that Islamic character education is a form of character education or noble values based on Islamic teachings. To anticipate intolerance and disintegration, the cultivation of Islamic education must be instilled from early childhood and carried out in all spheres of life, not only in the sphere of education but also in the family and society with the aim that the cultivation of Islamic character education achieves maximum achievement. And to be more optimal, this Islamic character education must be implemented directly with the method of habituation in daily activities, not just theory. The planting of Islamic character education that 
can be done as an effort to anticipate intolerance and disintegration includes.

Character of Religiosity

Religious character is usually understood as being obedient in carrying out religious orders. To be able to form this character, one must first provide insight into religious orders, especially in Islam, it must be accompanied by the arguments of Aqli and Naqli which originate from the Al-Qur'an and hadiths and are associated with phenomena in the surrounding environment, and provide real examples. like when ablution or prayer with the aim that the child understands better how to do the correct procedure.

One of the materials of religious orders that are often misinterpreted is the material of jihad (striving in the path of Allah). In explaining the material of jihad, it must be accompanied by arguments and balanced with the provision of insight into the peace that is highly respected in every religion. In delivering material both regarding religious orders, especially jihad, and material on peace, both teachers, parents, and the community must be neutral in other words, not fanatical towards one religion or radical in nature, and must have broad insights and perspectives.

Examples of cultivating this character include children being accustomed to praying five times a day seriously, where the heart, mind, and limbs both surrender to Allah or in other words no one's heart and mind think of anything. In addition, children can also be accustomed to being able to make peace with themselves when they are angry or when they are guilty, they must be able to forgive themselves and admit their mistakes and not explain their anger or mistakes to others. With sincerity and being able to make peace with oneself, a religious character will be formed accompanied by an understanding of the meaning of peace. So that the child can create a love for peace and understanding of the correct religion.

Honest, Discipline, and Responsible

This honest, disciplined, and responsible character must be accustomed to children from an early age with the aim that children are accustomed to being honest, disciplined, and responsible for what they say and do. In Sahih Bukhari book number 5630, it is explained that Rasulullah once said "There are three signs of a hypocrite, namely: when speaking lies, if he promises to deny, and if believed to be treasonous." (Bukhari: 5630) Based on the hadith, it is clear that being honest, disciplined, and responsible is very important. 
The three characters are tied to each other so that the cultivation of the three characters cannot be separated. The cultivation of these three characters with the habituation method can be started by getting the child accustomed to telling the truth, such as when going to leave the child is accustomed to asking permission first by saying where to go and go home at what time. And when the child does not come home on time or is not disciplined, the child must have the courage to be responsible by telling the truth about what happened to his parents.

In addition, in terms of prayer, especially prayer, children must be accustomed to being disciplined in performing the five daily prayers by exemplifying directly by praying in a congregation if there are no obstacles. And if the child is caught leaving one of them, then the child must have the courage, to tell the truth about the reason why he is leaving prayer and must be responsible by accepting the consequences given, for example, sanctions to increase memorization of short letters. With such habituation, the child will get used to it by itself to always say honestly, always be disciplined, and dare to be responsible.

Tolerance

Tolerance is an attitude of mutual respect, respect, and acceptance of existing differences. The existence of tolerance in the family, school, or society is very important (Munhamir, 2021). For example, accustoming children to respect those who are older than children by speaking politely, walking ducked when passing older people, accustoming children to deliberation in determining something, willing to listen to other people's opinions or not be individualistic, always greeting, greetings, and smile to everyone, always do good to others even though they are of different religions or others, do not choose friends based on wealth, religion, ethnicity, read stories about tolerance at the time of the prophets or guardians such as the story of tolerance being taught Sunan Kudus and others.

Love of Peace

To create a peace-loving character in children, it can be started by reading stories or stories about peace, especially peace exemplified by the Prophet during his life or other messengers of Allah such as prophets, guardians, or others who tell stories about peace, and get used to children when fighting to apologize if the child is wrong and forgive when asked for forgiveness, familiarize children not to fight or be hostile when disagreeing but prioritize deliberation, and others. 


\section{Gotong-royong}

Gotong-royong which is a characteristic of the Indonesian nation is very helpful in creating harmony. With cooperation, one can interact with many people, so that it will create harmony or peace in the community. The habit of cooperation can be started within the family, for example when cleaning the house for the recitation program, a family can work together with the division of tasks, sweeping, mopping, lifting tables and chairs, laying out mats, cooking dishes, and so on.

Meanwhile, cooperation at school can be done by familiarizing all students to participate in preparing for events that will be held by the school. For example, during a farewell ceremony at school, all students are asked to help arrange tables and chairs, decorate the stage, clean the event area, become performers, or others.

Cooperation in the community is often identified with cleaning activities, such as cleaning gutters, clearing the weeds around the house or school, or place of worship. During this environmental clean-up event, it can be used as an opportunity to accustom children to work together in the community and meet many people or neighbors who may be of different religions, ethnicities, races, or languages that can make acquaintances, exchange information, and even become good friends. So that harmony and peace can be created in the community, especially neighbors. In addition, cooperation that usually exists in the community which has started to rarely be practiced is mutual assistance helping neighbors when building houses, cooperation when neighbors have events, and so on. This distinctive character of the Indonesian nation must be preserved so that it remains for future generations.

National Spirit and Love for the Motherland

The spirit of nationalism and love for the country can be described in one word, namely nationalism. A nationalist character has been activated in Pancasila and Citizenship Education or PKN lessons. However, in this PKN learning only relies on theory without real practice, so that students are not able to live out this nationalist character. To realize this nationalist character, it is necessary to become accustomed to being tolerant towards fellow Indonesian citizens even though they are of different religions, ethnicities, races, languages, or cultures, prioritizing public interests over personal interests, participating in deliberations in making decisions, respecting differences of opinion. when deliberation, helping each other and also preserving cooperation, realizing peace in the absence of hostility, participating in post-camp activities to maintain community security, carrying out good values by religion and Pancasila, and so on. 
Friendly or Communicative

Being friendly or communicative is the main asset in establishing a relationship with someone. For this reason, children must be accustomed to always being friendly or friends with anyone and always communicating what they know, dare to apologize, when they have differences of opinion, they have the right to express themselves, not picky friends, like to consult and be able to bring themselves to them. surrounding environment (Zuhaida, 2021).

Caring for the Environment and Social

Care for the environment and society leads to the formation of a spirit of sympathy and empathy for the environment and social surroundings (Muhamir, 2021). An example of habituation to create a caring character for the environment is to provide an understanding to children that Islam loves cleanliness because cleanliness is part of faith which is then realized by providing an example for children to always throw garbage in its place so that flood does not occur, using water. as necessary so that there is no clean water crisis and even drought, likes to plant trees so that landslides or floods do not occur, likes and loves cleanliness by cleaning the environment where children are, and many others.

Social care characters can be created from the habit of always sharing, such as when the month of Ramadan invites children to cook and then distributes food to people who want to break their fast on the street or to neighbors, when a beggar comes, ask the child to give money or food when a neighbor dies to ask the child to take part in the pilgrimage to the neighbor's house to comfort the abandoned family and pray for the deceased neighbor, ask the child to visit and pray for his sick friend to get well soon when there is a disaster outside the area ask the child to share with sorting out clothes that are no longer used but are still good for donation to people affected by disasters or setting aside their allowance to donate, and much more.

Tawassuth or Moderate

Tawassuth or moderate is the same, namely choosing the middle or neutral way to a problem (Shaifudin, 2020: 31). To create this important character in children, it is necessary to get used to reading books about the diversity of religions, ethnicities, cultures, customs, or languages to enrich children's insights about the many diversity in this world. In addition to adding insight, reading books can also give children a broad perspective in assessing a problem. 
Other habits that can be done to create this character are by getting children to always consult when they have different opinions, mediating between friends who have disagreements (Zuhaida, 2021), not judging thieves, not accusing people who have different views of themselves as bad people. or hypocrites or apostates and even polytheists, and so on.

Based on the above explanation, it can be seen that intolerance and disintegration can be anticipated by planting Islamic character education which is by Islamic principles and noble values in Pancasila which can be accustomed to children from an early age both in the family, school, and community environment. And with the habituation method that is carried out from an early age and in all spheres of life can shape the character of the child by itself without any compulsion. One character with another character is related or related to one another.

\section{Conclusion}

Intolerance and disintegration in a country full of diversity like Indonesia can be anticipated by instilling Islamic character education. The values in Islamic character education are following the values contained in the teachings of Islam and Pancasila. In the cultivation of Islamic character education, to obtain maximum results, it can be applied with the familiarization method for children from an early age in all spheres of life, both in the family, school, and society. Cultivating Islamic character education with habituation methods that can be done, including familiarizing children to always share with everyone, getting children to ask permission when they want to go, inviting children to participate in cooperation or community service cleaning the surrounding environment, getting children to read books from various literature that can bring broad insights and perspectives to children, dare to apologize and are willing to forgive people who apologize, like to deliberate when there are differences of opinion, and others. With habituation, Islamic character education can be embedded in children without coercion but because they are used to it. And all those characters are related and related to each other.

\section{REFERENCES}

Arifianto, A. R. (2017). Practicing what it preaches? Understanding the contradictions between pluralist theology and religious intolerance within Indonesia's Nahdlatul Ulama. Al-Jami'ah, 55(2), 241-264. https://doi.org/10.1442 1/ajis.2017.552.241-264 
Assyaukanie, L. (2018). Legal Roots of Intolerance and Discrimination in Indonesia. MAARIF, 13(2), 27-42. https://doi.org/10.47651/ mrf.v $13 \mathrm{i} 2.20$

Azca, M. N., Ikhwan, H., \& Arrobi, M. Z. (2019). A tale of two royal cities: The narratives of Islamists intolerance in Yogyakarta and Solo. AlJamiah, 57(1), 25-50. https://doi.org/10.14421/ajis.2019.571.2550

Bukhari, Imam. Sahih Bukhari. Retrieved 6 April. https://carihadis.com/ Shahih_Bukhari/5630

Dewi, I. M. (2015). Conflict and Disintegration In Indonesia. MOZAIK: Jurnal Ilmu-Ilmu Sosial Dan Humaniora, 6(1), 91-102. https://doi.org/10.21831/moz.v6i1.4400

Fatwikiningsih, Nur. 2020. Psychological Theory of Human Personality. Yogyakarta: Publisher Andi.

Fithriyah, M. (UIN S. S. K. R., \& Umam, M. S. (IAIN K. (2018). Internalization Of Aswaja Values In Islamic Education As A Deradicalization Effort To Good Citizen. UNWAHA, 1, 110-124. http://ejournal.unwaha.ac.id/index.php/asdanu/article/view/239

Herlina, L. (2018). Social Disintegration In Facebook Social Media Content. TEMALI: Jurnal Pembangunan Sosial, 1(2), 232-258. https://doi.org/10.15575/jt.v1i2.3046

Koesoema A., Doni. 2007. Character Education. Jakarta: PT. Grasindo.

Munhamir, Irham (PMII IAIN Kudus activist). Interview by Fa'iz Nashiroh. Institut Agama Negeri Kudus. April 17, 2021.

Ramadhan. (2017). Educational Environment in the Implementation of Character Education. Jurnal Pendidikan UNIGA, 8(1), 28-37. http://digilib.uinsgd.ac.id/id/eprint/5 122

Redaksi, D. (2020). Table of Contents. Jurnal Statistika Universitas Muhammadiyah Semarang, $8(2)$. https:/ / doi.org/10.26714/jsunimus.8.2.2020.ii-iv

Sanusi, I., \& Muhaemin, E. (2019). Religious Intolerance in Newspaper Framing Compass. Communicatus: Jurnal Ilmu Komunikasi, 3(1), 1734. https://doi.org/10.15575/cjik.v3i 1.5034

Sataloff, R. T., Johns, M. M., \& Kost, K. M. (2017). The Education of the National Character of Pancasila in Secondary School Based on Pesantren. Jurnal Cakrawala Pendidikan, 36(3), 423-434. https://doi.org/10.21831/cp.v36i3.15399 
Shaifudin, A. (2020). Islamic Education for the Integrity of the Unitary State of the Republic of Indonesia (NKRI). El-Wasathiya, 8(1), 2940 .

Shihab, Quraish. 2011. Tafsir Al-Misbah. Accessed 6 April 2021. http://tafsirq.com/2-al-baqarah/ayat-208\#tafsir-quraish-shihab

Sholikin, A. (2018). Intolerance, Radicalism, and Terrorism in Lamongan. Jurnal Polinter: Kajian Politik Dan Hubungan Internasional, 4(1), 120.

http://journal.uta45jakarta.ac.id/index.php/polhi/article/view/12 75\%oAhttp://garuda.ristekbrin.go.id/documents/detail/971740

Sukendar, A., Usman, H. , \& Jabar, CSA (2019). Teaching-loving-caring and semi-military education on character education management. Educational Horizons, 38(2), 292-304. https://doi.org/10.21831/ cp.v38i2.24452

Sukiyat. 2020. Character Education Implementation Strategy. Surabaya: CV. Jakad Media Publishing.

Supratikno, A., Hudiono, R. K., Maria, E., \& ... (2020). Developing a Creative Peace Tourism Village as an Effort to Bring Shalom amid the Threat of National Disintegration. KURIOS (Jurnal Teologi ..., $6(2), \quad 330-345 . \quad$ https://www.sttpb.ac.id/e-journal/index.php/ kurios/article/view/228

Supriyadi, E. (2011). Education and character assessment in vocational high schools. Cakrawala Pendidikan, 110-123.

Sutomo, I. (2014). Modification of character education into akhlaq education for the global community life - Indonesian Journal of Islam and Muslim Societies PDFijims.iainsalatiga.ac.id > article > download. Indonesian Journal of Islam and Muslim Societies, 4(2), 291316.

Tholkhah, I. (2013). The Potential of Religious Intolerance of School Students in Java and Sulawesi. EDUKASI: Jurnal Penelitian Pendidikan Agama dan Keagamaan, 11(1), 1-18. https://doi.org/10.32729/edukasi.v11i1.422

Triatmanto. (2010). Challenges Of Implementation Of Character Education In School. Jurnal Cakrawala Pendidikan, 1(3), 187-203. https://doi.org/10.21831/cp.v1i3.245

Zuhaida, Khusna (IPPNU Purwosari Kota Kudus activist). Interview by Fa'iz Nashiroh. Institut Agama Islam Kudus. 17 April 12021. 
